\title{
Air Sebagai Entitas Keadilan: Refleksi Akademik Pendekatam Environmental Justice dalam Krisis Air di Bali
}

\author{
Victorius A. Hamel \\ Fakultas Ilmu Sosial Politik Universitas Warmadewa, Denpasar, Bali-Indonesia \\ victrhame171@gmail.com
}

\begin{abstract}
Water is a very important need in human life, but it is an entity of justice as well. The water crisis in Bali provides a strong signal that an act of injustice for the living community around the tourism enclaves in Bali. This water crisis is not the source of the environmental crisis, but also from a governance that does not provide a wide space for distributive and participatory justice processes through an environmental justice approach. This articel is a literature study approach which methodologically discusses and express it as an academic-reflective: "Water is not only an entity of life but also contains the meaning of justice.
\end{abstract}

Keywords: Water; Water Crisis; Environtmental Justice

\section{Abstrak}

Air merupakan kebutuhan yang sangat penting dalam kehidupan manusia. Tetapi air juga merupakan sebuah entitas keadilan. Krisis air di Bali memberikan sebuah sinyal kuat bahwa terjadi tindakan ketidakadilan yang dirasakan oleh masyarakat di sekitar wilayah kantong-kantong daerah pariwisata di Bali. Krisis air ini bukan semata bersumber semata pada krisis lingkungan tetapi juga bersumber pada tata kelola yang tidak memberi ruang yang luas bagi proses keadilan distributif dan partisipatif melalui pendekatan environmental justice. Tulisan bersifat studi literatur yang kemudian secara metodologis mendiskusikannya serta menuangkan sebagai catatan reflektif-akademik: "Air adalah bukan hanya sebuah entitas kehidupan tetapi juga mengandung makna keadilan.

Kata Kunci: Air, Krisis Air, Keadilan Lingkungan

\section{Pendahuluan}

Air merupakan kebutuhan utama setiap mahluk hidup. Tanpa air tentu akan berdampak sangat fatal bagi kehidupan. Dengan demikian, sejak awal air telah menjadi sesuatu yang sangat penting artinya, bukan saja dalam pengertian fungsi dan kebutuhannya, tetapi juga dalam hal terkait tata kelola akses terhadap air. Negara-negara, dalam hal ini Indonesia, juga sangat memperhatikan tata kelola air untuk kebutuhan masyarakat secara umum. UUD 1945, pasal 33: 3 mencantumkan dengan jelas kata air sebagai hal utama dalam sistem tata kelola perekonomian di Indonesia:

"Bumi dan air dan kekayaan alam yang terkandung di dalamnya dikuasai oleh negara dan dipergunakan untuk sebesar-besar kemakmuran rakyat".

Tampak dengan jelas bahwa negara, dalam hal ini perintah sejak awal pembentukan negara Indonesia, telah menyadari akan kompleksnya penataan terhadap masalah air di Indonesia, yang notabene adalah negara kepualan yang sebagain besar wilayahnya diliputi oleh air (laut). Dengan demikian tata kelola air tidak saja terkait dengan bagaimana menata kelola distribusi air secara sistimatis kepada masyarakat tetapi di dalamnya mengandung unsur-unsur yang lebih kompleks seperti nilai-nilai keadilan, kesamaan hak, kemudahan akses terhadap sumber-sumber air, teknologi

CC-BY-SA 4.0 License, Copyright 2021, Journal of Contemporary Public Administration (JCPA) 
terhadap air dan juga penataan lingkungan atau sumber-sumber itu tersebut.

Tulisan ini memfokuskan pada persoalan-persoalan air yang muncul di Bali. Bali, seperti yang kita ketahui adalah sebuah destinasi pariwisata yang sangat terkenal di dunia. Pemerintah Orde Baru sejak awal pemerintahannya telah melihat Bali sebagai sebuah daerah dengan potensi pariwisatanya yang sangat besar. Sejarah memang mencatat Bali adalah sebuah daerah dengan segala keunikannya yang terbentang luas dari timur, barat, utara dan selatan kepulauannya. Setiap daerah dan wilayah yang ada di Bali mengandung unsur-unsur keindahan yang tidak ternilai harganya, sebuah keluhuran dalam peradaban masa lalu yang masih terjaga hingga kini.

Namun demikian, sejak digulirkannya "politik pariwisata" terhadap Bali, maka banyak hal yang terkait dengan konteks ke-Bali-an mulai tergerus dan menimbulkan beragam masalah. Salah satu masalah yang muncul adalah krisi air di Bali.

Krisis air terjadi di Bali. Ini mungkin bukan sesuatu yang mengejutkan, karena para ahli telah memberikan indikasi yang sangat kuat melalui hasil penelitian-penelitian mereka. Di samping itu, sisi lainyang menambah keterkejutan itu adalah muculnya isu-isu environmental justice (selanjutnya disebut keadilan lingkungan atau disingkat KL) dalam tata kelola air. Konsep ini bergulir mengingat persoalan air bukan saja pada bagaimana menata kelola air secara prosedural berdasarkan kebijakankebijakan yang ada di Indonesia, tetapi juag memiliki unsur-unsur yang berdampak pada isu keadilan terhadap manusia sebagai pengguna air dan juga air sebagai unsur dalam lingkungan.

Penulis memfokuskan tulisan ini berdasarkan beberapa data yang telah dilansir, di mana terdapat daerah-daerah yang kondisi airnya sudah sangat kritis, khususnya di daerah kantongkantong pariwisata. Mengapa dikhususkan pada daerah kantong-kantong pariwisata, karena terdapat korelasi penggunaan air tanah yang besar di daerah tersebut oleh hotel-hotel, Villa bersama dengan masyarakat yang hidup di sekitarnya. Secara historis kebanyakan model pengembangan pariwisata di Bali sama sekali tidak meniadakan unsur masyarakat/penduduk yang sudah ada di sana sejak lama. Masyrakat ada bersama-sama dengan pengembangan pariwisata. Sehingga keberadaan masyarakat yang tinggal di sekitar daerah pariwisata bertumbuh bersama dengan perkembangan pariwisata itu dengan sendirinya. Hotel-hotel, Villa-Villa di bangun, begitu juga dengan sentra-sentra hiburan pariwisata lainnya.

Namun demikian kisah indah pertumbuhan pariwisata di Bali tidak selalu semulus dengan keindahan pertumbuhan masyarakatnya terkait dengan krisis air yang terjadi. Kebanyakan masyarakat yang tinggal di sekitar daerah kantong-kantong pariwisata tersebut secara langsung terdampak dari persoalan krisis air bersih di Bali. Menjadi pertanyaan hingga saat ini adalah tidak banyak terdengar protes sosial terhadap kondisi krisis air ini, apakah dalam hal ini masyarakat menerima kondisi ini dengan "pasrah" dan tidak bisa berbuat apa-apa dengan kebijakan-kebijakan yang terkait dengan distribusi air bersih atau memang masyarakat sama sekali tidak mengetahui bagaimana sebenarnya proses-proses peruusan kebijakan-kebijakan terkait dengan distribusi air ini baik secara nasional maupun lokal (dilevel Propinsi dan Kabupaten)?

\section{Metode Penelitian}

Dalam penulisan ini penulis menggunakan studi literatur dan hasil studi lembaga terkait yang sudah meneliti secara spesifik tentang krisis air di Bali dan menganalisanya melalui pendekatan Environmental Justice atau Keadilan Lingkungan (selanjutnya disebut KL). Isu utama dari pendektan KL adalah bagaimana mengurai persoalan-persoalan keadilan dari perspektif humanhuman kepada human - non-human, di mana dalam hal ini membangun kesadaran bahwa alam tidak bisa diabaikan guna membangun kesadaran keadilan. Dalam hal ini air sebagai sebuah nature kosmik yang ber-sifat given, namun dalam perspektif tata kelola publik menjadi bisa tidak bebas dalam pengertian baik penggunaannya, distribusi dan juga dampak yang diakibatkan dari penggunaan air (dalam hal bisnis-nisnis yang menggunakan air). Oleh karenanya tata kelola air menjadi penting dalam perspektif KL, karena terkait dengan bagiaman distribusi erhadap air dapat ditinjau berdasarkan prinsip-prinsi keadilan, dalam hal ini melalui pendekatn KL.

\section{Hasil dan Pembahasan}




\section{Environmental Justice (Keadilan Lingkungan)}

Penulis menggunakan pendekatan KL dalam tulisan ini karena melalui pendekatan ini ingin melihat bagaimana usaha meningkatkan distribusi keadilan khususnya dalam konteks human-human dan juga human-non-human. Seperti kita ketahui, dalam banyak percakapan tentang keadilan, aspek keadilan cenderung hanya dikaitkan dalam domain human-human. Tetapi pertanyaaannya selanjutnya adalah apakah keadilan juga terkait dengan isu-isu non-human? Menurut Baxter, dalam perkembangannya konsep keadilan, perspektif human-non human sama sekali tidak bisa diabaikan, mengingat keduanya sangat mempengaruhi satu dengan yang lainnya (Baxter, 2005).

Peneliti menyadari bahwa sejarah KL adalah bermula di dalam konteks Amerika. Seperti diketahui di era tahun 1970-1980-an di Amerika sendiri memiliki persoalan ketidakadilan terhadap orang-orang kulit berwarna, sehingga menimbulkan isu rasialisme. Namun hal ini tidak saja terkait di antara persoalan hubungan antar manusia tetapi juga terkait dengan lingkungan, di mana penempatan limbah-limbah industri ditempatkan di wilayah-wilayah atau kantong-kantong masyarakat yang nota bene adalah orang-orang kulit berwarna (black people). Hal ini kemudian menimbulkan isu yang sangat sensitif terkait dengan hubungan rasialisme dan isu lingkungan (United States Environmental Protection Agency, 2021). Rodhes (2003) menyebut hal tersebut sebagai 'the environmental racism. Ini berarti bahwa persoalan KL tidak sesederhana yang dipikirkan karena ia menyangkut berbagai hal terkait seperti manusia, lingkungan, kebijakankebijakan dan juga proses-proses distribusi yang sudah barang tentu sangat kompleks dalam realitanya (Bowen, 2001). Distribusi yang bersifat adil (justice) dan memiliki kesamaan hak dan kesempatan (equity) adalah dasar utama dalam pembahasan mengenai keadilan lingkungan. Lebih luas Frechette (2002), menegaskan bahwa paling tidak ada dua hal terkait distribusi yang harus mendapat perhatian sungguh-sungguh dalam pembahasan mengenai KL, yaitu keadilan distributif dan keadilan partisipatif. Keadilan distributif menyangkut bagaimana distribusi seperti kekayaan, kesempatan, pendidikan, pembuangan limbah beracun, udara kotor, dan sebagainya di antara anggota masyarakat, dengan tetap menjaga nilai-nilai secara berkeadilan dan manusiawi. Dengan kata lain memiliki dampak yang positif dan bukan negatif. Sedangkan keadilan partisipatif adalah keadilan yang memberi ruang yang besar bagi perumus kebijakan maupun masyarakat untuk berpartisipasi dalam proses perumusan dan evaluasi kebijakan terkait dengan isu-isu yang meyangku KL. Warga masyarakat memiliki hak untuk menolak fasilitas berbahaya yang menempatkan risiko yang tidak proporsional atau menerimanya. Misalnya dalam KTT National People of Color Environmental Leadership Summit tahun 1992, ketika mereka mengadopsi 17 prinsip keadilan lingkungan, mereka secara eksplisit menuntut keadilan partisipatif. Pada prinsip kelima mereka menegaskan hak untuk menentukan nasib sendiri bagi semua orang, dan prinsip ketujuh mereka menegaskan: "Keadilan lingkungan menuntut hak untuk berpartisipasi sebagai mitra setara di setiap tingkat pengambilan keputusan (Frechette, 2002)". Di sini aspek keadilan berkelindan dengan hal kesetaraan. Bullard dalam (Finger dan Zorzi, 2013) menyebutkan bahwa di sebagian besar misi keadilan maka akan muncul tiga kategori besar dalam isu kesetaraan yaitu: keadilan prosedural, keadilan geografis dan keadilan sosial. Keadilan prosedural adalah keadilan yang terkait dengan perangkat-perangkat aturan yang dikeluarkan oleh pemerintah. Keadilan geografis adalah berfokus pada lokasi komunitas dan kedekatannya dengan bahaya yang disebabkan oleh lingkungan di sekitarnya. Sedangkan keadilan sosial mengacu pada faktor sosiologis (ras, etnis, kelas, budaya, gaya hidup, kekuatan politik, dll) yang terkait dengan pengambilan-pengambilan keputusan mengenai lingkungan di sekitranya (Finger, Zorzi, 2013).

Memperhatikan hal-hal di atas, kembali pada isu air yang ada di daerah kantong-kantong pariwisata, pertanyaannya adalah apakah muncul isu rasialisme dalam konteks di Bali? Peneliti tidak memfokuskan pada hal itu tetapi meminjam fokus utama dari pendekatan KL di atas yaitu adanya korelasi antara masyarakat, lingkungan dan kebijakan-kebijakan negara terhadap isu utama yang akan diteliti. Dalam hal ini adalah masalah air di Bali. Dengan demikian persoalan KL dalam kasus air di daerah kantong-kantong pariwisata di Bali sangat terkait erat dengan prinsip-prinsip keadilan distributif dan keadilan partisipatif sekaligus juga berkelindan dengan tiga hal pokok khususnya mengenai tata kelola (dalam hal ini pemangku kebijakan - pemerintah), objek materi yang dipersoalkan (air), serta masyarakat yang terkena dampak dari persoalan tersebut.

\section{Air dan Persoalan Kebijakan}

Di banyak negara persoalan air telah terurai bukan saja menjadi isu bagaimana memanfaatkan air tetapi juga telah menjadi masalah politis. Menjadi masalah politis karena di dalamnya

CC-BY-SA 4.0 License, Copyright 2021, Journal of Contemporary Public Administration (JCPA) 
mengandung problematika kekuasaan, distribusi keadilan dan juga tata kelola dalam hal kebijakan publik. Akibatnya, hal itu juga dapat memicu konflik secara vertikal dan horizontal jika di dalamnya tidak terdapat keadilan untuk mengatasinya. Studi kasus di India seperti yang diungkapkan oleh Dik Roth, dkk., memberikan indikasi yang jelas bahwa dalam hal air sebagai kebutuhan utama masyarakat, dalam tata kelolanya terdapat komponen-komponen yang sangat menentukan bagaimana alokasi yang berorientasi pada keadilan distribusi itu terjadi. Penguasa (pemerintah), pengusaha, "penguasa" teknologi, masyarakat, sering kali berlomba untuk mendapatan lapisan teratas untuk mengakses sumber-sumber air. Dengan demikian entitas air yang tadinya bersifat netral dan alami tersebut tidak lagi menjadi netral dan alami tetapi menjadi bias berdasarkan kepentingankepentingan tersebut (Rutgert, 2018). Sultana dan Loftus (2020) mengatakan bahwa hal itu menunjukan hak-hak atas air seperti yang tertuang dalam resolusi PBB mengenai hak atas air dan sanitasi tahun 2010 dalam prakteknya tidaklah mudah karena berhimpit dan bersaing dengan kepentingan-kentingan dari komponen-komponen yang ada di dalam konteks publik. Meskipun dalam terminologi mengenai "hak atas air" juga tidak bebas diskursus, karena seperti tiga pertanyaan Thielborger (2014) ketika mendiskusikan mengenai persoalan hak atas air: 1) Apakah air itu sendiri memiliki kandungan yang dapat diperdebatkan sebagai sebuah hak? 2) Apakah pendekatan hukum yang sesuai dengan kebutuhan dasar manusia akan air adalah hak? 3) Apakah hak atas air ini benarbenar dapat dikualifikasikan sebagai hak asasi manusia? Tiga pertanyaan ini menunjukan kompleksitas persolan air di level implementasi kebijakan dan juga dalam level dinamika sosial.

\section{Persoalan Air dan Pariwisata di Bali}

Tidak banyak referensi yang membahas mengenai hubungan keduanya. Tetapi catatan dari Michalis Hadjikakao (Hadjikakao, Miller \& Chenoweth, 2013) dalam artikelnya menegaskan kembali bahwa perlu sekali penelitian-penelitian yang lebih dalam terhadap persoalan air dan pariwisata. Menurutnya, hubungan yang paling penting dari isu air dan pariwisata adalah fakata bahwa pembangunan pariwisata sangat membutuhkan pasokan air bersih yang banyak sekali. Pada sisi lain dipahami bahwa turisme adalah pengguna utama yang menjadi salah satu faktor kelangkaan air bersih dan persoalan-persoalan lainnya terkait dengan entitas air di sebuah destinasi pariwisata. Hadjikakao menegaskan:

Khususnya di negara berkembang di mana pendapatan per kapita nasional rendah, perbedaan antara lokal dan konsumsi wisatawan cenderung besar. Sebuah studi oleh Gössling (2001) menunjukkan bahwa rata-rata per kapita penggunaan air harian di hotel-hotel di Zanzibar setara dengan sekitar 15 kali permintaan per kapita harian dari penduduk setempat. Hal ini dapat sudahbarang tentu menimbulkan masalah ketidakadilan sejak turis-turis menjadi pengguna air yang bernilai lebih tinggi daripada penduduk lokal. Fakta lain adalah bahwa sebagian besar wisatawan berasal dari negara-negara beriklim maju di mana air melimpah. Oleh karena itu, mereka sering tidak tahu bagaimana menggunakan secara baik dibandingkan dengan penduduk setempat.

\section{(Hadjikakao, Miller \& Chenoweth, 2013)}

Penegasan mengenai eratnya hubungan antara air dan pariwisata semakin tampak dari modelmodel pengembangan pariwisata yang semakin modern, yang cenderung lebih banyak memerlukan air. Pembangunan hotel-hotel mewah, Villa-Villa besar, lapangan golf, kolam renang mewah dan besar, taman bermain air, dsb., telah memberikan indikasi yang jelas bahwa pariwisata tidak terbebas dan bertanggungjawab terhadap persoalan kelangkaan/kebersihan air. Meskipun pariwisata bersifat sangat musiman tetapi tampak dengan jelas bahwa penggunaan air di musim panas telah memperparah kondisi air di daeah kantong-kantong pariwisata. Dengan membeirkan catatan statisik perbandingan dengan beberapa kota di berbagai negara, Hadjikakao mengungungkapkan :

Statistik dari berbagai wilayah Mediterania seperti wilayah Provence-Côte d'Azur di Prancis, kelompok pulau Cyclades di Yunani dan Costa Brava di Spanyol menunjukkan bahwa populasi di resor wisata dapat meningkat lebih dari sepuluh kali lipat selama waktu-waktu tertentu dalam setahun. Akibatnya, kebutuhan air seringkali melebihi air ketersediaan selama bulan-bulan musim panas. Oleh karena itu, resor musim panas biasanya terpaksa mengandalkan air tanah, dimana pemompaan air tanah yang besar dapat menciptakan masalah kualitas air, misalnya intrusi air asin (di mana air asin dari laut ditarik ke akuifer. Penyebab fenomena ini adalah pengambilan air tanah yang berlebihan untuk penyediaan air publik yang sebagian besar berasal dari pariwisata di daerahdaerah tertentu.

(Hadjikakao, Miller, Chenoweth, 2013)

CC-BY-SA 4.0 License, Copyright 2021, Journal of Contemporary Public Administration (JCPA) 
Kondisi umum yang dipaparkan di atas dalam kaitan air dan pariwisata tampaknya juga menjadi isu yang sangat penting di Bali. Paling tidak ada dua hasil penelitian yang dapat menjadi acuan memahami kriis air di Bali. Penelitian dai IDEP yang bekerja sama dengan Politeknik Negeri Bali menghasilkan penelitian yang bersifat lebih umum tetapi hasilnya tetap memperlihatkan bahwa daerah kantong-kantong pariwisata memiliki tingat krisis air yang lebih tinggi di banding daerah lainnya.

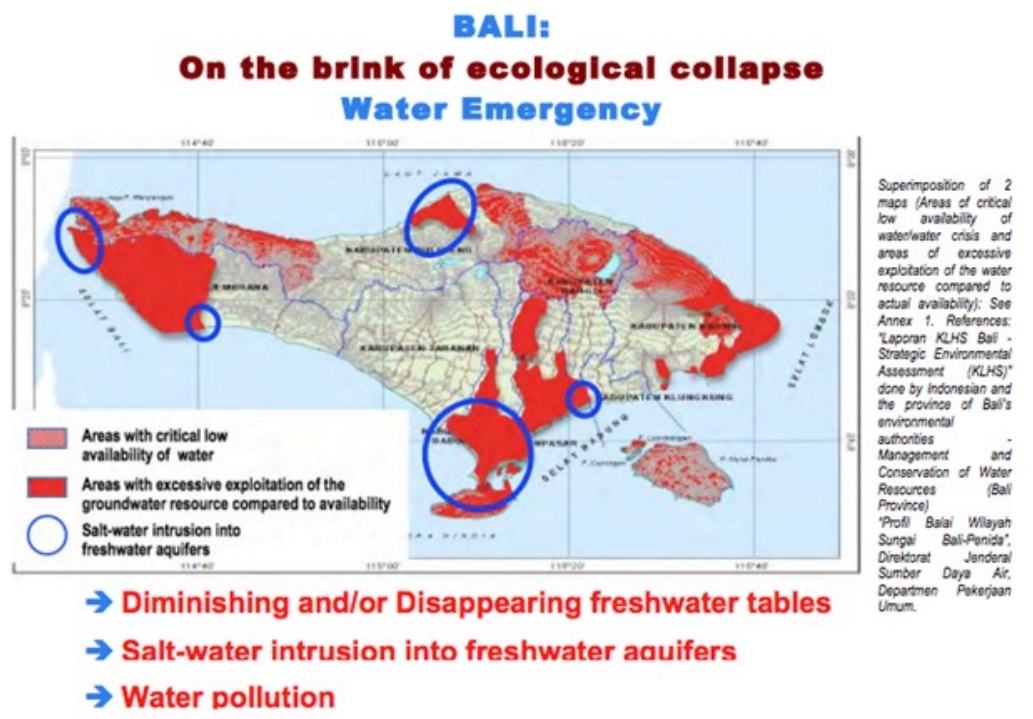

Gambar 1. Intrusi Air Laut dan Polusi Air di Bali

Sumber: Bali Water Protection (2017)

Ilustrasi di atas memberikan gambaran umum bagaimana kondisi krisi air di Bali secara umum di daerah kantong-kantong pariwisata. Tampak bagian-bagian yang berwarna merah menunjukan adanya kekuarangan air bersih, intrusi air laut yang memasuki aquifer dan adanya polusi terhadap air bersih. Pendekatan IDEP (IDEP Foundation, 2017) memang sangat teknikal dengan penemuanpenemuan secara umum antara lain:

Permukaan air Bali telah turun lebih dari 50 meter di beberapa daerah dalam waktu kurang dari 10 tahun dan banyak sumur mengering atau dengan air kotor, terutama di bagian Selatan

Danau Buyan (cagar alam air tawar terbesar kedua di Bali) telah turun 3,5 meter dalam 3 sampai 5 meter pada 2012;

$60 \%$ DAS Bali dinyatakan kering

Air asin bergerak ke memasuki aquifer di beberapa daerah di selatan khususnya seperti Sanur/ Suwug, lebih dari 1 kilometer ke pedalama dari garis pantai dan di daerah Kuta, Legian dan Seminyak, lebih dari 10 meter

Peningkatan gangguan sirkulasi air di beberapa daerah hanya memungkinkan satu kali panen padi per tahun, bukan dua hingga tiga kali seperti biasanya; baru-baru ini lebih dari 50\% waduk baru Tabanan awalnya dibangun untuk pertanian padi sawah, telah dialihkan ke Bandung Selatan untuk Pariwisata

Beberapa catatan di atas ini tentunya merupakan sebuah alarm bagi Bali, yang oleh Stroma Cole (2012) meneliti secara khusus munculnya persoalan-persoalan di atas melalui pendekatan ekologi politik. Cole mengurai dengan jelas kompleksitas tata kelola air di Bali dengan mengajukan sebuah tesis yang tegas bahwa terjadi carut marut tata kelola air di Bali, akibat tumpang tindihnya pola-pola pengambilan keputusan dari setiap stakeholders yang terkait dengan air:

Setiap departemen diwakili pada tingkat yang berbeda dalam sistem pemerintahan Indonesia: Nasional, Provinsi dan Kabupaten. Departemen tingkat nasional menetapkan aturan yang harus diikuti di tingkat Provinsi, yang sendiri mengikuti dan membuat aturan untuk diberlakukan di tingkat Kabupaten. Namun, sejak 1999 Indonesia memberikan otonomi kepada Kabupaten sehingga

CC-BY-SA 4.0 License, Copyright 2021, Journal of Contemporary Public Administration (JCPA) 
mereka sering membuat aturan sendiri dan menolak untuk mematuhi aturan yang dibuat lebih tinggi dalam sistem administrasi. "Sayangnya, Bupati dapat dan sering mengabaikan pemerintah provinsi dalam hal-hal penting seperti mengoordinasikan pendekatan berkelanjutan untuk pengelolaan sumber daya dan pengembangan pariwisata". Hasilnya adalah banyak aturan tetapi tidak ada yang bertanggung jawab untuk menegakkan aturan yang ada. Hampir setiap responden dari desa hingga kepala dinas mengatakan kepada kami bahwa masalahnya adalah "penegakan hukum yang lemah" "kurangnya kontrol terhadap pelanggar hukum" "peraturan tidak berfungsi" "pengawasan lemah" atau bahwa "hukum tidak diterapkan".

\section{(Cole, 2012)}

Catatan penting di atas memberikan indikasi bahwa ada masalah mengenai tata kelola air di Bali, di mana salah satunya hal itu bersumber dari proses pengambilan-pengambilan kebijakan yang tumpang tindih satu dengan lainnya di antara pemangku kebijakan air di Bali. Nada kritis dari Cole (2012) ini memang tidak bisa diabaikan ketika kita melihat dampak dari kriris air dalam berbagai faktor penemuan penelitiannya. Untuk fator dampak terhadap masyarakat adalah terkendalanya supplai air bersih dengan segala persoalannya. Faktor regulasi, munculnya birokrasi yang sangat panjang terkait dengan proses pengambilan keputusan baik di ranah Propinsi dan Kabupaten, seperti yang di tunjukan dalam kutipan di atas. Faktor sosial dan kultural menunjukan bahwa konteks tersebutl di Bali telah menutup ruang-ruang kritis terhadap carut marut tata kelola air ini. Cole (2012) menyatakan bahwa sikap penghormatan yang terlalu tinggi terhadap sebuah otoritas, apakah itu bersifat kultural dan dalam konteks birokrasi pemerintahan (misalnya kepada kepala pemerintahah lokal), telah membuat sebagai besar masyarakat tidak lagi dapat secara terbuka mau mengritisi apa yang dilakukan oleh pihak-pihak yang berada "di atas". Dalam hal carut marutnya tata kelola air akibat proses kebijakan yang tidak maksimal hal ini sangat tampak, demikian Cole (2012), bahwa partisipasi masyarakat tidak terlihat di dalamnya secara optimal, bahkan yang terjadi justru sebaliknya yaitu muncul masalah baru: munculnya konflik yang bersifat horizontal di aras masyarakat.

Pada faktor kesadaran, tampak bahwa ada masalah penggunaaan air yang begitu besar di lingkungan pariwisata. Para turis berpikir Bali tidak sedang mengalami krisis air sehingga pola penggunaan air menjadi begitu boros, di sisi lain para penyedia jasa pariwisa memberikan layanan yang berlebihan untuk para turis guna menikmati pulau Bali yang indah ini. Yang menggembirakan, menurut Cole (2012), hampir 70\% turis mengatakan mereka akan membuat upaya untuk menghemat air dan ingin lebih banyak informasi untuk membantu krisi air di Bali. Sementara itu 36\% bersedia membayar pajak lingkungan atas tagihan mereka untuk membantu menghemat air dan $12 \%$ lebih lanjut akan membuat sukarela berkontribusi untuk penghematan air di Bali.

Faktor pembangunan lingkungan, proses deforestasi dan pembangunan sarana-sarana pariwista di lingkungan utama penampungan air, bahkan proses aspalisasi jalan-jalan, telah menambah persoalan lingkungan di kawasan pariwisata terkait dengan air. Begitu juga persoalan alih fungsi lahan yang terjadi secara masif dalam penelitian Cole (2012) terjadi di daerah CangguKuta Bali), telah memberikan indikasi bahwa persoalan air telah bertumpang tindih atas nama pembangunan pariwisata di Bali.

\section{Posisi Masyarakat, Pemerintah dan Pengusaha}

Penelitian Cole (2012) memberikan gambaran yang jelas bahwa terlalu banyaknya pemangku kebijakan di aras lokal terkait dengan kebijakan air di Bali. Ini telah memberikan gambaran betapa persoalan kebijakan air bukanlah hal yang mudah untuk diurai. Ketidakmudahan itu berdampak pada model peratisipasi masyarakat yang sangat minim dalam proses pengambilan keputusan. Masyarakat, dalam hal ini pelaku bisnis pariwisata, cenderung bersifat pasif, dalam pengertian hanya sebagai pengguna air dan belum banyak memikirkan bagaiman kelangsungan keberadaan air di Bali. Sementara itu masyarakat kebanyakan/rumah tangga hanya mengandalkan saluran air dari pemerintah (PDAM) yang tidak pernah tahu dari mana asal muasal air tersebut. Ini menyebabkan tingat partisipasi masyarakat juga semakin kurang dan cenderung tidak kritis terhadap kondisi air di Bali. Tidak pernah terjadi demonstrasi atau protes secara terbuka perwakilan masyarakat terhadap tata keolala air oleh pemerintah dan/atau kepada pelaku-pelaku pariwisata (Hotel besar, Villa, manajemen Lapangan Gof, Kolam Renang berskala besar, dll). Pertanyaannya mengapa tidak ada protes terhadap hal-hal tersebut?

Salah satu faktor yang Cole (2012) sebutkan di atas adalah faktor kultural di mana masyarakat

CC-BY-SA 4.0 License, Copyright 2021, Journal of Contemporary Public Administration (JCPA) 
Bali yang bersifat hirarkis. Namun menurut penulis harus dikembalikan pada pertanyaan mengenai entitas air dalam pendektan KL, yaitu khususnya pada pertanyaan apakah air itu sendiri memiliki kandungan yang dapat diperdebatkan sebagai sebuah hak? Apakah hak atas air ini benar-benar dapat dikualifikasikan sebagai hak asasi manusia? Dua pertanyaan ini tampaknya tidak mudah untuk dijawab mengingat air sendiri dalam konteks Bali lebih cenderung dimaknai dalam perspektif yang lebih religius ketimbang sesuatu yang bersifat sosial. Air, dalam perspektif religius/teologis lebih banyak di lihat sebagai anugrah yang turun dari langit dan kemudian memasuki ruang-ruang suci dan kemudian diyakini memberikan dorongan spritual yang besar bagi masyarakat (Bali). Perspektif religiusitas tidak pernah mempertanyakan apakah sumber-sumber yang menyebabkan terjadinya krisis air di Bali, karena dipahami memang bukan domain yang utama dari perspektif religiusitas. Akan tetapi lebih berfokus pada menjaga dan merawat keberadaan air dan situs-situs sucinya. Pada sisi lain sumber-sumber air secara masif telah mengalami titik-titik yang sangat krisis atas nama pencemaran, intrusi air laut, kurangnya curah hujan, dan tentu tata kelola yang sangat bermasalah di sana-sini. Dengan kata lain entitas air belum dilihat sebagai bagian dari persoalan hak-hak kemanusiaan, karena sebagian besar masyarakat masih melihat hal ini sebagai sebuah fenomena alam (non-human) yang turun begitu saja dari langit.

Pada sisi lain keberadaan masyarakat lokal di sekitar daerah kantong-kantong pariwisata telah merasakan munculnya persoalan air. Penulis sempat mewawancarai seorang ibu rumah tangga yang tinggal di sekitar Legian mengeluh karena air dari PDAM di lingkungannya perumahnnya sering mati dan terkadang kotor. Sehingga tidak bisa digunakan untuk mencuci pakaian, peralatan dapur lainnya atau memasak. Demikian juga air dari sumber sumur galiannya juga terasa payau dan tidak nyaman digunakan untuk mandi. Seorang pemilik villa skala rumah tangga di daerah Seminyak juga mengatakan hal yang sama ketika diwawancarai: "Kami selalu dikomplain oleh tamu-tamu yang menginap di Villa kami ketika akan pulang, karena air yang mereka gunakan untuk mandi terasa sedikit asin. Ini bukan saja terjadi pada Villa kami tetapi juga Villa-Villa di sekitar sini. Tetapi kami tahu Hotel-Hotel yang besar menggunakan alat yang dapat menawarkan air laut dengan harga yang cukup mahal (800-an juta), kami tidak bisa menjangkau untuk membelinya”.

Dua ungkapan ini tentu tidak bisa dianggap sebagai representasi keberadaan masyarakat di daerah kantong-kantong pariwisata, tetapi paling tidak hal ini bisa merefleksikan beragam persoalan yang sebenarnya muncul mengenai persoalan air bersih di Bali. Rasa frustasi ibu-ibu rumah tangga yang tidak dapat menggunakan haknya untuk menggunakan dan menerima air bersih dan juga tamutamu yang komplain atas pelayanan di Villa skala rumah tangga, memberikan catatan bahwa terjadi ketidakadilan dalam distribusi hak atas air di aras masyarakat. Ketidakmampuan mereka untuk mengritisi pemerintah dan bersaing dengan para pemilik hotel besar yang memiliki modal untuk membeli alat pemurnian air laut adalah tanda ketidakadilan mulai menyeruak di lingkup masyarakat. Dengan kata lain terjadi terjadi disikriminasi melaui kompetisi yang tidak adil antara penguasa (pemerintah), pengusaha, "penguasa" teknologi, masyarakat, yang berlomba untuk mendapatan lapisan teratas untuk mengakses sumber-sumber air. Ketidakadilan itu muncul di mana masyarakat tidak akan pernah memenangkan kompetisi tersebut karena lapisan-lapisan teratas untuk mengakses sumber-sumber air itu lagi-lagi hanya berada di tangan para pemilik modal yang berkolaborasi dengan kekuasaan. Hal ini mungkin menjadi sanada dengan apa yang diungkapkan oleh Finger dan Zorzi (2013) dalam artikelnya yaitu paling tidak menurut mereka ada dua isu penting yang perlu dilihat dalam hal analisis KL terhadap tindakan negara/pemerintah dan kekuatan politik masyarakat:

Pertama, negara sering kali gagal untuk menjamin hak-hak komunitas atau masyarakat (miskin). Cara utama pemerintah dapat mengambil bagian dalam menentukan lokasi fasilitas berisiko adalah bersifat pasif dan aktif. Secara pasif, industri mengambil peran utama dalam menemukan tempat untuk fasilitasnya dan kemudian meminta izin negara, dan secara aktif, negara menentukan wilayah di mana fasilitas tersebut dapat berada, dan kemudian membuat zonasi wilayahnya. Dalam kedua hal ini maka ketidakadilan lingkungan akan terus dilanggengkan. Di satu sisi ketika perusahaan mencari lahan meletakan limbah-limebahnya maka cenderung memilih wilayah yang murah yang biasanya ditempati oleh kelompok orang yang berpenghasilan rendah atau daerah pemukiman minoritas yang pada kenyataannya tidak memiliki daya tawar yang kuat baik terhadp pemerintah maupun perusahaan. Kedua, masyarakat minoritas tidak selalu memiliki kekuatan untuk mempengaruhi keputusan pemerintah, ketidakstabilan politik mencegah mereka dari memaksakan tuntutan dan kebutuhan mereka kepada para politisi .. komunitas tersebut kurang mampu mengejar hak-hak mereka utuk memperoleh penegakan hukum yang adil.

Finger dan Zorzi (2013)

CC-BY-SA 4.0 License, Copyright 2021, Journal of Contemporary Public Administration (JCPA) 


\section{Simpulan}

Dari pembahasan di atas tampak dengan jelas bahwa persoalan krisi air di Bali tidak saja memerlukan perhatan yang serius secara admistratif tata kelola melalui kebijakan-kebijakannya yang konprehensif dan tertata secara sinergi di antara pemangku-pemangku kebijakan (kelembagaan), tetapi juga adalah pentingtnya sebeuah kesadaran bahwa lingkungan adalah bagian yang penting juga untuk dimaknai dalam locus yang lebih tegas yaitu keadilan. Keadlilan bukan saja untuk kepentingan human-human tetapi juga human - non human. Bali sebagai salah satu daerah pariwisata utama di Indonesia seharusnya tidak tereskploitasi secara masif, jika prinsip-prinsip keadian lingkungan diperhatikan. Pemerintah dan pengusaha seharusnya tidak menjadikan Bali sebagai sumber ekonomi tanpa memperhatikan lingkungannya bertumbuh dengan baik. Para pelaku pariwisata besar seharusnya menyadari bahwa pembukaan dan pengembangan zona-zona pariwisata bukan saja terkait dengan perijinan oleh dan dari pemerintah semata tetapi juga memperhatikan masyarakat di sekitarnya (pasif). Begitu juga dengan pemerintah daerah kiranya memperhatikan setiap ijin yang diberikan untuk pengembangan kewilayahahan daerah-daerah pengembangan pariwisata dengan memperhatikan juga konteks dan masyarakat di sekitranya (aktif). Jika hal ini terabaikan maka prinsip ketidakadilan terhadap masyarakat akan terus terjadi, begitu juga sebenanrya dengan alam sekitarnya, khususnya dalam kasus air. Penguatan tata kelola air sebenanrya bukan saja menciptakan sebuah sistem administrasi publik yang berkontribusi postif bagi masyarakat tetapi lebih dari pada itu juga adalah memberikan ruang filosofis yang lebih dalam untuk menegaskan bahwa hak atas air adalah sebuah prinsip yang di dalamnya tergantung nilai keadilan dan juga secara kualitatif merujuk pada prinsip-prinsip hak asasi manusia. Dengankata lain sistem admnistrasi publik atau atat kelola air yang buruk secara jelas berkorelasi pada termarginalisasinya nilai-nilai keadilan dan juga hak asasi manusia. Dalam kasus air di Bali, sistem administrasi publik atau tata kelola air yang tidak terkontrol dengan baik dapat dikataan telah menyebabkan munculnya persoalan ketidakadilan, khususnya dalam hal mengakses kebutuhan air bersih oleh masyaraat yang tinggal di sekitar daerah kantong-kantong pariwisata dan itu menjadi persoalan dalam pembahasan hak -asasi manusia.

Tulisan ini sekali lagi bersifat reflektif-akademik dan memberi ruang besar bagi penelitian lebih lanjut mengenai isu KL dalam hal krisis air di Bali. Tersebar catatan-catatan penting di dalamnya, secara khusus dengan menguaknya isu ketidakadilan dalam hal distributif dan partisipatif. Dengan demikian sebuah kesadaran harus dibangun bersama: "Air adalah bukan hanya sebuah entitas kehidupan tetapi juga mengandung makna keadilan". Oleh sebab itu harus diperjuangakan, bukan saja bagi penggunanya - khususnya masyarakat (dalam hal ini yang berada di sekitar dearah pariwisata), tetapi juga menjaga air dan segala situs-situs sucinya dari segala kecemaran yang melingkupinya. Menjaga air, menjaga Bali.

\section{Daftar Pustaka}

Baxter, B. (2005). A Theory of Ecological Justice. London and New York: Routledge Taylor \&Francis Group.

Boelens, R., et al (Eds.) (2018). Water Justice. United Kingdom: Cambridge University Press.

Bowen, W. M. (2001). Environmental Justice Through Research - Based Decision -Making. New York and London: Garland and Publishing.

Cole, S. (2012). A political Ecology of Water Equity and Tourism: A Case Study From Bali. Annals of Tourism Research. 39(2), 1221-1241. Doi: https://doi.org/10.1016/j.annals.2012.01.003

Finger, M. D. O., \& Zorzi, F. B. (2013). Environmental Justice. UFRGS Model United Nations Journal. 1, 222 -243. Retrieved from https://www.ufrgs.br/ufrgsmun/2013/wp-content/uploads/2013/10/ Environmental-Justice.pdf

Frechette, K. S. (2002). Environmental Justice - Creating Equality, Reclaiming Democracy. New York: Oxford University Press.

IDEP Bali dan Politeknik Negeri Bali. (2017). Bali Water Protection. Retrieved from https:// www.idepfoundation.org/images/idep/how-you-can-help/support-a-project/bali-water-protectionprogram/bwp_agama_tirtha.pdf 
Victorius A. Hamel: Air Sebagai Entitas Keadilan: Refleksi Akademik Pendekatam Environmental Justice dalam Krisis Air di Bali

Journal of Contemporary Public Administration (JCPA), Volume 1, Nomor 2, Mei 2021

Hadjikokou, M., Chenoweth, J. L., \& Miller, G. (2013).Water and Tourism. Retrieved from https:// www.researchgate.net/

publication/242013756_Book_chapter_on_Water_and_Tourism\#: :text=10.13140/RG.2.1.2356.5286

Rodhes, E. L. (2003). Environmental Justice in America. Bloomington, IN: Indiana University.

Sultana, Farhana \& Loftus, A (eds). (2020). Water Politics - Governance, Justice and Right to Water. London \& New York: Routledge Taylor \& Francis Group.

Thielborger, P. (2014). The Right(s) to Water - The Multi-Level Governance of a Unique Human Right. Bohum-Germany: Springer

United States Environmental Protection Agency - https:/www.epa.gov/environmentaljustice/learn-aboutenvironmental-justice 